PUBLISHED IN

Baden Offord. 'Singapore, Indonesia and Malaysia: Arrested Development! ' In The lesbian and gay movement and the state: Comparative insights into a transformed relationship. Manon Tremblay, David Paternotte and Carol Johnson (eds.), (London, Ashgate: 2011). pp.135-152 ISBN 9781409410669

\title{
ARRESTED DEVELOPMENT! SINGAPORE, INDONESIA AND MALAYSIA
}

Baden Offord

\section{LG ACTIVISM IN SOUTHEAST ASIA}

The focus of this chapter is on lesbian and gay (LG) activism in three neighbouring countries in Southeast Asia: Singapore, Malaysia and Indonesia. To understand the extent to which the State has influenced the LG movement in each of these countries there are a set of theoretical protocols needed in transferring the language and practice of lesbian and gay activism that are often more or less derived and self evident in Western polities, into a specific Southeast Asian context. As Michael G. Peletz (2007) has remarked about the study of gender, body politics and sexualities in Asia, there are dynamics at work in Asian cultures and societies that do not make it necessarily inevitable that LG activism will mirror what has developed in the West. On the other hand, homosexual rights activists across Asia do engage with modernity, liberalist positionings, transnational queer activists and human rights frameworks in their struggles.

Having researched sexuality, activism and human rights in Southeast Asia and Australia over fifteen years (see Offord 1999, 2003a, 2003b, 2006), my position as a queer theorist working in the Western academy presents immediate problems for social and cultural analysis in Asian contexts where contradictions and paradoxes can arise between well-meaning emancipation scholarship and the oppressive neo-colonial realities of that very same scholarship. This does not mean that research on LG activism in Southeast Asia is paralysed conceptually, because as Anjali Arondekar (2007: 338) puts it, there are 'pathways... that vigilantly reimagine the vastness of sexuality's locations and its analytical frames.' 
Much has been written over the last decade about the difficulties, ambivalences, challenges and usefulness faced in queering Asia (and the narrow LG focus of this book could be regarded in this context as counter-productive given there are a range of gender and sexual identity norms across countries such as Indonesia and Malaysia) (see Altman 2001; Offord 2003a; Boellstorff 2007; Peletz 2007; Ho 2008; Wilson 2006; Blackwood 2008). To enable critical sensitivity, Evelyn Blackwood and Saskia Wieringa (2007) have argued for an approach that is informed by actively decolonising global queer studies. The basis of their approach is to make visible and question. the Western terms of reference when studying sexualities in diverse non-Western contexts, that is, proposing research that is reflexively oriented as well as empirical.

Salient considerations within a decolonising global queer studies approach, question a range of frequently accepted assumptions and motivations. These include, for instance, questioning the universalist activist 'desire for visibility' - frequently a Western construct linked to ideas of strong identity politics, which may not always be possible or legitimate forms of activism in Asia or non-Western contexts where there exists soft identity politics and politicisation of sexual identity may not always be the primary goal (Blackwood and Wieringa 2007: 4); evolutionary perspectives on sexuality that promote the idea that modernity has liberated sexual identities from the metropolitan, scientised West into the rest of the world; 'the tendency to essentialise and universalise human experiences by assuming the relevance of "Western" categories' (Blackwood and Wieringa 2007: 4), that is, where the gay template in the West is discoverable everywhere; challenging the notion that only through a politicised rights based activism will change occur; and the notion of 'coming out' as lesbian or gay, a very strong discourse developed in the West and accepted in legal, psychological and political terms, but which is not relevant in the same way as a psychological/cultural or legal event in Southeast Asia (Heng 2004). LG activism does itself function across cultures in different ways - whether in the global north or south. LG movements are characterised by, for example, their geo-political context, history, social, and economic conditions.

All these factors underpin an examination of LG movements in regions such as Southeast Asia. Peletz (2007: 87) paraphrases Manderson and Jolly’s (1997:2) view, therefore, that "we need to be wary of discursive genealogies and "theories of 
development which conceive a teleological trajectory" whereby the West becomes "a dress rehearsal for the rest of the world.",

The central argument of this chapter is that in Indonesia, Singapore and Malaysia, the extent to which the LG movement has been influenced by the State can be gauged through the way the State regulates (socially, legally, culturally) and denies (politically) homosexuality. Each of these countries has specific colonial histories, ethnic, religious, social and cultural conditions (Johnson, Jackson and Herdt, 2000). Malaysia and Indonesia, for example, are Muslim nations while Singapore is not. While the focus of the chapter is on how the state regulates sexuality, an important caveat to be made is that the state may well be over-privileged as a rubric of analysis as the effects, among others, of globalization and postcolonial queer resistance are also crucial factors in understanding LG activism (Obendorf 2010).

As will be seen in the following survey, the indices of what characterises the LG movement shows that in Singapore, Malaysia and Indonesia, these movements are absent, nascent and/or not politicised in the same way that can be observed across the West or indeed parts of the global South such as in South Africa. Change for LG people is taking place in Southeast Asia but not in terms of explicit political action and lobbying. Houben (2004: 80) argues that in Southeast Asia, 'the nation state dominates the relationship with society, producing a conservatively biased, "selective" kind of globalization which incorporates economic liberalization, some cultural elements, but hardly any of the political dimensions.' Thus, questions of sexual liberation in the Stonewall tradition are mediated by this 'nanny state' relationship. And, although there are social, media (particularly new media), cultural and health spaces that exist for LG activists and LG people in general, they are more or less regulated, constrained and not primarily political organising spaces.

\section{LG SOUTHEAST ASIAN ACTIVISMS AND THE STATE}

Tiptoeing in the 'Nanny State': Nation Parties, Yawning Bread and Pink Dots in Singapore: LG Activism, Governance and the State. 
The LG movement in Singapore has emerged in socially, culturally and politically specific ways. In one sense, it can be described as quiet and politically inconsequential, but there is a resilient and growing LG community and the concerns and articulations of Singaporean LG activists are creative, extensive, media savvy, interactive and politically astute. At times, the LG activist voice has crossed over into the mainstream and affected the national debate about larger questions of citizenship and sexual diversity (Offord 2003b). The State influence on the LG movement, however, has been exceedingly powerful and marked by surveillance, repression, regulation and control. Sexuality in Singapore is micromanaged by the State through its various apparatuses and agencies, including the law. Significantly, homosexuality remains illegal in Singapore under Section 377A of the Penal Code (colonially inherited from Macauley's Indian Penal Code). The legal situation has been extensively analysed by a number of authors (for example Offord 2003a; Leong, 1997; Sanders 2005; Yue 2007; Chan 2009), and remains a keystone to the State's management of diverse sexualities.

In recent history, visible but highly restricted social spaces for homosexuals were evident in the 1960s (the famous Bugis Street for example) but it was through the 1980s that a more visible LG community in terms of an opening up of civil society and non-governmental organisations, as well greater representation through literature and theatre, occurred. The 1980s were a watershed period where LG sexual identities were forged against a backdrop of greater social venues and contact but also affected by the advent of AIDS, which brought greater monitoring and regulation by the State on the activities of homosexuals as well as the formation of non-governmental organisations such as Action for AIDS, which provided a space for activist thought through legitimated health discourses (see Leong 1995).

In the 1990s the first attempts were made to organise a more deliberative LG movement based on liberalist notions of the individual and the international human rights discourse. The formation of People Like Us (PLU) in 1993 was the most significant. $P L U$ 's mission was to normalise homosexuality in Singapore through education and to de-criminalise homosexuality (Offord, 2003a). In order to be a legitimate organisation in Singapore's civil society and to therefore act in the public sphere, non-government organisations need to be registered with the Government. PLU attempted to do this in 1996 but failed. During the 1990s, however, the LG movement 
did gain enormous momentum through other forms of communication and organisation, mainly through media and performance space and crucially through the Internet (see $\mathrm{Ng}$ 1999). Kadir (2004: 347) has remarked that 'Cyberspace remains the hardest space for the government to control.' As a consequence, sites such as Yawning Bread, PLU, SiGNel flourished as key conduits of political, social and cultural commentary and dialogue about homosexuality in Singapore (Offord, 2003b). It is evident these have had a direct impact on everyday life in (a wired) Singapore, that there are robust discussions on sexual rights and citizenship that are sophisticated and informed. What was clear during the 1990s, though, was that, '... civil society groups [had to] walk a fine line between seeking and expansion of public space and protecting themselves from being co-opted or eradicated... [I]n Singapore this is a tightrope walk' (Kadir 2004: 347). This perspective cogently explains and characterises the context facing the LG activist in their relationship to the State.

The first decade of the twenty first century began with positive signs for the LG movement. In 1997, the goals of Singapore 21, enunciated by former Prime Minister Goh Chok Tong in which Singapore needed to be a creative polity which drew on all of its citizens, and which needed to be open to challenges to the status quo, appeared to pave the way for greater engagement between the State and civil society (Offord 2003a; Yue 2007). From 2001 to 2004 there appeared to be greater social interaction and visibility, for example, through the Nation Parties, which drew thousands of people and led international observers to think that Singapore had become the 'out' place to be (Price 2003). Other websites emerged such as Fridae (www.fridae.com) in 2001, a large LG portal, as well as Pelangi Pride Centre and the RedQuEEn! website for lesbians, which all demonstrated growing resources for the LG movement.

A pivotal change in Government policy in 2003 towards homosexual employees in the civil service, where explicit homosexuals could be employed (see Tan 2009) also led to the perception that the State was becoming open to its LG citizens. However, in 2004 the Government retreated to its well-established position. 'The rapidly growing gay visibility... alarmed the government, which needed to put homosexuals back in their place' (Goh 2008: 388). In 2004, the government through the media stated that homosexuality was the cause of HIV/AIDS, and a second attempt by $P L U$ to register was rejected. As a consequence of public and Government debate about the Nation 
Party (an outdoor explicitly gay event held on the same day as Singapore's National Day from 2003 to 2005) in which arguments were made that it contributed to HIV/AIDS in Singapore, the event was also banned.

The history of the LG movement in Singapore is thus one of expanding homosexual visibility and socio-cultural recognition (and in many ways a greater normalization of homosexuality in everyday life). But this has been in tandem with the State, which has, following its pragmatic and illiberal approach to homosexuality, sustained an instrumental approach to managing sexual citizenship in the legal and public spheres. Thus, following a speech by Elder Statesman Lee Kuan Yew in 2007 about what he saw as the 'inevitability of legalizing homosexuality,' the Government 'irrationally clamped down on gay activists in the country' (Yue 2007: 158), yet another instance of the State's intervention into sexuality and the nation.

The gay activist, academic and playwright Russell Heng (2001) has therefore characterised the Singaporean LG movement as tiptoeing out of the closet and that against any measurement within a 'global queer spectrum,' lesbians and gays are in a process of finding their own form of activism in what many describe as the "nanny state" (Heng 2004). In 2005, Prime Minister Lee Hsien Loong's attitude was that homosexuals should go about things "quietly" as Singaporeans do not like to see change happening suddenly (Goh 2008: 394). Attenuating this, Kadir (2004: 347) underscores the fact that 'civil society activism in Singapore does not involve confronting the state or undermining it.' This is important to note, as Audrey Yue (2007: 158) has pointed out what she calls the illiberal pragmatism of Singapore queer culture where activism is asymmetrical and unpredictable. She argues that rather than following a trajectory as a result of 'the recognition of rights and liberation,' 'queer culture' in Singapore, 'has been constituted... through the disjunctive acceleration caused by economic and cultural reforms.' In other words, Yue argues that other forms of LG emergence are happening, not (always or systematically) through rights discourse, but enabled through cultural and economic liberalisation and mobility.

Sociologist Laurence Leong (1997), on the other hand, has argued that Singapore, in terms of the socio-legal controls is one of the final frontiers for homosexual liberation. Certainly, given the nature of this postmodern, technocratic, globalised, authoritarian city-State that quintessentially exhibits all the stresses that 
come from the intersection of capitalism, interconnected communications and localised identity, LG activists negotiate a schizophrenic culture that at once rejects their legitimacy and also invites their participation as citizens of the State. In this sense the Singaporean Government has actively pacified the LG movement. However, although there is a very demure politicised LG movement, this has not stopped the emergence of social and cultural spaces for LG activity.

Thus, people like Alex Au, the eloquent activist who steers and authors much of the website Yawning Bread, (a key site of LG activist thinking on all matters of the State) are able to speak back to the State and its influence and affect on the LG citizen (see Offord 2003b). As Tan and Lee (2007: 200) observe:

The strategy of gay activists has been to pursue their goals by riding on official discourse and rhetoric. One example of this is the way Singapore 21, Remaking Singapore, and the economically motivated talk of liberalization have made it possible for gay activists to demand formal equality with other citizens as a right that is wholly compatible with, indeed required by, any serious pursuit of the ideals articulated so eloquently in the official rhetoric.

Following Michel Foucault (1984: 24), sexuality in Singapore is 'regulated' by the State 'for the greater good of all.' Interestingly, a recent development of the LG movement in Singapore has been the organization of the Pink Dot day, first held in 2009. The event, a carnival-like cultural performance, brings people together to celebrate their support for the LGBT community. Held on 16 May 2010, significantly to coincide with the International Day of Families, the Pink Dot event in 2010 drew 4,000 people and was the largest public gathering ever held at Speaker's Corner in Hong Lim Park, 'Singapore's only government-designated venue for public assembly and free speech where a police permit is not required' (Tan 2010a). In what could be a new cycle of gaining new space in the public sphere in Singapore, one of the organizers stated: 'I think it is groundbreaking in that this is the first time Singapore television has reported on a local LGBT-supportive event in positive terms' (quoted in Tan, 2010a). The LG movement in Singapore thus negotiates the spaces available in ways that are more frequently cultural and social in expression rather than overtly political. 
(In)Visible in the Shadows of Islam: the Influence of the State on the LG Movement in Malaysia

Adam, Duyvendak and Krouwel posit that there are a range of prerequisites in relation to the viability and existence of a national LG movement. These are first and foremost predicated on the basis of sexual identity, which when deployed into a community or a people, allows an LG movement to be imagined and organised (Adam, Duyvendak and Krouwel 1999: 350-351). Another vital dimension is whether there is a national civic culture that can support LG activism or organization.

In Malaysia, which is a semi-authoritarian democratic and Islamic State, the civic culture that exists has excluded the presence of explicit LG organisations. Homosexuality is illegal and over the last two decades and more has been framed as a border between 'Asia' and the West through powerful politicians such as the former Prime Minister Mahathir Mohamad who has actively used the State to regulate and even expunge homosexuality from any movement of legitimation. Through a confluence of legal, religious, political and socially conservative means, Mahathir and his successors have continued to construct State sponsored homophobia that is specifically tied to Islam (Williams 2009).

First by a reliance through the 1990s on a Malaysian template of democracy derived from 'Asian Values', which were constructed to produce the idea that Western forms of democracy would lead to homosexuality, a Western and decadent practice (Offord 2003a). Second, the infamous criminal charges of sodomy laid against former Deputy Prime Minister, Anwar Ibrahim in 1998, and which led to Anwar's imprisonment and a sustained attack and demonization of his so-called homosexual behaviour to the present, have been based on a specific State sponsored reification of homosexuality as a cultural border. The Malaysian government has purposefully deployed homosexuality as an unwelcome effect of globalisation and Western neocolonialism (Berman 2008; Johnson 2006).

Given that sexuality (and gender) in Malaysia is circumscribed by an ensemble of powerful influences that cohere around the State's maintenance of religious, cultural and ethnic boundaries, the emergence of a coherent LG movement based on sexual identity is largely absent. In terms of surveying Malaysian homosexuality, it does exist 
in both visible and invisible ways, but always in the shadows of Islamic and Malay cultural and religious identity (Kasim 2006), which are tightly conflated by the State and managed by the core institutions of Malaysian society, particularly through the Islamic and State legal systems and largely state controlled media (Kasim 2006; Berman 2008; Williams 2009).

In this Southeast Asian country, which borders Singapore, national identity is firmly based on Islam. Although Malaysia is a religious and pluralist society, the dominant Malay culture and Islamic religion determine the State's character, structure and interpretation of legitimate forms of sexuality and morality. The government is defined on Islamic principles (Williams 2009: 8). Indeed, similar to Singapore, Malaysia's 'state, government, and party are largely fused in practice... the United Malays National Organisation (UMNO) has dominated' the Government since independence from the British in 1957. Although the public sphere in Malaysia is considered to be far more diverse and open to dissent than other Southeast Asian polities, and the civic culture is quite active (Weiss 2004: 260-261), the specific constraints that affect LG activism are severely impacted upon by an Islamic-centred society and by the State and State sponsored institutions. Malaysia's strong civic culture according to Meredith Weiss (2004) is predicated upon Islamic-oriented rather than secular NGOs, which proscribe specific limits to which LG activism can exist, develop or be visible.

The Malaysian LG experience and any nascent signs of activism remain problematically under-researched since homosexuality and explicit LG identity in the public sphere is regarded in essence as 'beyond the pale'. As Kasim (2006: 50) has observed, (citing Ramakrishnan, 2000) about the complex cultural and legal norms that inhibit same sex relations in Malaysia:

Laws, both civil and Shariah, have over the years criminalised certain sexual practices, some of which explicitly target same-sex couples. Same-sex sexual relations, particularly between men, is often demonised as "un-Islamic," "unnatural," "disgusting,"... "a crime worse than murder".

There are four key features that explain the entrenched extent to which State sponsored homophobia exists. First, Malay culture is derived from social and cultural 
mores that, as Norhazlina Yusop (2004: 36-37) argues, were historically quite tolerant towards homosexuality but this has been challenged over the last fifty years through the construction of the Malaysian State. The advent of an independent, postcolonial State of Malaysia witnessed a fusion and intensification of state power [and] increasing authority of religious orthodoxy' (Yusop 2004: 40) against a backdrop of colonialist structures.

Second, there are no publicly acknowledged legitimated LG rights discourses in Malaysia, and indeed homosexuality is illegal (Laurent 2005; Kassim 2006; Berman 2008). As Douglas Sanders (2007) has remarked, 'there is no public discussion of sexual diversity, no discussion of the criminal law still in place.' The situation for LG people in Malaysia is constrained and limited to the shadows and made largely invisible through State and religious suppression of homosexuality and same sex relations. As Raymond Tai of the Malaysian NGO Pink Triangle notes (quoted in Tan, 2008a):

The marginalisation of gay men in Malaysia (as a result of the highly moralistic and conservative society, a hostile media and the rise of political Islam) has also led to a lack of a gay community culture and consciousness.

And yet, homosexuality is also deliberately made visible at times when it is invoked as a demarcation of what is acceptable or foreign to Malaysian society. The Malaysian State has reified homosexuality into the public sphere over the last two decades through a range of exclusionary strategies based on its demonization, dehumanisation, illegality, Westernisation (see Berman 2008) and immorality, which according to P. N. Alagappar's (2009) analysis of the New Straits Times, Malaysia's leading English daily, has represented homosexuality in overwhelmingly negative terms over the last decade and more. Alan Berman (2008) in his recent analysis of former Prime Minister and now Elder statesman Mahathir Mohamad, observes:

The perceived threat to the state from the homosexual other was important to Mahathir in fashioning Malay gendered subjectivities... Mahathir viewed the homosexual other as undermining social cohesion and ultimately the ability of the nation-state to endure in its present form. 
The deleterious influence of the State on the LG movement in Malaysia has therefore been profound, built on the 'government's stated goal of "wiping out" homosexuality in Malaysia' (Williams 2009: 16).

Third, activist attempts at organising around sexual identity have occurred primarily within health discourse frameworks and specifically around HIV/AIDS through the work of Malaysia's oldest LG organisation, Pink Triangle. Although this national organisation is explicitly focused on sexual health, it has been an important conduit for LG nascent community formation and education (Kassim 2006: 51).

Fourth, the Malaysian Government's political and moral assassination (1998 to 2010) of former Deputy Prime Minister Anwar Ibrahim through his incarceration and criminalisation for homosexuality, has enabled the State's active antagonism towards homosexuality in broader legal, political, social and religious terms (see Berman 2008 for an extensive analysis), to produce a highly charged public sphere where homosexuality is deployed as an ongoing feature of corruption and an affront to Islam. This also precipitated, however, forms of transnational LG activism in support homosexual rights and queer Malaysians and in a sense invoked homosexuality into the public sphere as an identity and possibility (Obendorf 2006).

Yet, in a society where 'sexuality is under attack... with a growing obsession with guarding and policing morality' (Kasim 2006: 1), the influence of the State on the LG movement is dangerous and complex. Zaltun Mohamad Kasim (2006) has observed that this is because civil society organisations that assist LG people are not able to explicitly challenge State, civil or Shariah laws, which oppress and discriminate against diverse sexualities. Despite these severe strictures, Malaysian LG concerns, like those in Singapore, are at times expressed in culturally specific ways. In 2008, for example,

As thousands of Malaysians marched in a massive parade at Merdeka (Freedom) Square on Sunday to celebrate the country's 51 years of independence from Britain, the LGBT community created its own slice of history with its first ever sexuality rights festival held across the Klang River at Central Market Annexe (Tan 2008b).

However, such events are rare and have not translated into any political or legitimated space for LG activism. The influence of the LG movement on the Malaysian 
State as a consequence has been negligible. Walter Williams (2009: 17) sees the State's active goal of 'wiping' out homosexuality through an ensemble of laws against sodomy, 'imprisonment, censorship... police oppression,', and systemic government oppression of LG people through State sponsored organisations and severe restrictions on LG representation and human rights, as evidence of State led homophobia and persecution of homosexuality.

\section{The Gay Archipelago and its Paradoxes: the Influence of the State on LG Activism in Indonesia}

The influence of the State in Indonesia on the LG movement, on the hand, is perhaps the most paradoxical in this overview of Southeast Asia. As the largest Muslim nation in the world, Indonesia is for the most part regarded as moderate when it comes to Islam (and tolerant of homosexuality - particularly in terms of traditional identities such as waria who may be transgender or transsexual) although there are provinces such as Aceh - and several Islamic movements, which are clearly fundamentalist and/or follow Islamic Shariah law similar to Malaysia. As King Oey, (quoted in Sabarini, 2008), founder of the LG organisation, Arus Pelangi, says: 'Indonesia is not a country based on religious law; however the rigid interpretations of religious teachings are sometimes fused into the legal system.'

The LG movement in Indonesia has been perhaps the most visible across this part of Southeast Asia (excluding therefore Thailand and the Philippines) in terms of its presence in civil society (Graham 2006; Oetomo 2010) and there are a number of organisations that represent LG interests and activism. In 1982, Lambda Indonesia, the first LG organisation was formed. Through the 1990s LG organisations spread throughout the archipelago and in 1993 the first Indonesian Lesbian and Gay Congress was held in Yogyakarta. Indonesia's first Gay Pride celebration took place in Surabaya, in June 1999. Other organizations that are present in the public sphere, which address LG issue and representation include: Persatuan Lesbian Indonesia (Indonesian Lesbian Union), Gaya Nusantara (founded in 1987), Chandra Kirana, Jaringan Lesbian \& Gay Indonesia (Indonesian Gay and Lesbian Network) and Koalisi Perempuan Indonesia 
untuk Keadilan dan Demokrasi (Indonesian Women's Coalition for Justice and Democracy) (Offord 2003a; Boellstorff 2005; Blackwood 2007).

The State's influence on the LG movement is complex and ambiguous. Evelyn Blackwood (2007) argues that the increasing visibility of 'alternative sexualities' and the State's response can be seen through three distinct periods. First, the New Order period under Suharto (pre-1998) 'sought to control sexuality through a deployment of gender. During this time the print media occupied a vital position in popularising and stigmatising certain representations of homosexuality' (Blackwood 2007: 294). Second, during the 1990s, as a response to international movements towards same sex marriage, Blackwood's analysis shows how the Indonesia State and Islamic discourses around homosexuality intensified. The third period Blackwood (2007: 294) identifies is in the post Suharto period where:

an increasingly vocal conservative Islamic minority pushed for more restrictive laws in the State Penal Code governing sexual behaviours and public morals, initiating an intense public debate on the role of the state in questions of sexuality. Over this time period, discourse on sexuality moved from strategically linking normative gender with heterosexuality and marriage to directly legislating heterosexual marriage through efforts to criminalise a wide range of sexual practices.

Since 1998, Indonesia has been a society under enormous stress and change post the Suharto dictatorship era. The country's fledgling democratic governments have faced increasingly Islamicised pressures on the State in terms of governance and law. In the post September 11, 2001 climate, the rise of militant Islamic groups and certain extreme forms of atavistic behaviour across Indonesia led to endemic and pervasive violence. This was targeted at ethnic minorities and towards explicitly identified homosexuals, who were often perceived to be Western corrupted individuals or deviants. Explicit targeting by hard line Islamic groups against homosexuals include the Indonesian Council of Ulemas, Indonesia's top Muslim clerical body; Islamic Defender Front, an extremist group that is known for violent tactics; and the Hizb ut-Tahrir Indonesia. 'At its core... Indonesia is a homophobic society when it comes to the recognition of homosexuality as something normal' (Sabarini 2008). 
This 'creeping' Islamisation of Indonesia has had a widespread impact on the perception of what is considered normal and appropriate moral behaviour. Many provinces in Indonesia have adopted traditional Shariah law, which explicitly condemns homosexuals and is discussed further below. The adoption of an Anti-Pornography Bill by the Indonesian Parliament on 30 October 2008 defines pornography in such a broad manner that even someone's effeminate gestures may be regarded as pornographic. An effeminate gay man could face 12 years in prison. Opposition politicians, scholars and human rights bodies have expressed alarm that this Bill can be used as a means of extending and entrenching Shariah Law in Indonesian society (see Allen 2009).

Indonesian society is predicated on extremely strong filial relations in which the notion of individuality familiar to Western cultures is regarded as irrelevant and even immoral. The family principle in Indonesia - kekeluargaan - is the basic social thread that binds the Indonesian State together. In my research over the years with gay Indonesians, for example, sexual identity is placed well after the priorities of family, nation, and Allah or Jesus, and has no explicit place in filial and social relations (Offord 2003a). As Blackwood (2007: 295) argues, 'Discourse on sexuality in Indonesia is deployed in a number of forms that are part of and separate from the state, including discourses of family, marriage, community and religion.'

There is also a deeply embedded 'heterosexism' in Indonesia, which means that any deviation from heteronormativity is seen as dishonourable and shameful. Boellstorff $(2005,2007)$ has observed the steadily rising political homophobia in Indonesia layered on this heterosexism. Although concealed and unspoken homosexuality may be tolerated to exist to some degree within certain select elements of Indonesian society, explicit homosexual identity is regarded as an illness (sakit) and is the target of social exclusion, violence, and other forms of physical, psychological and emotional persecution (Immigration and Refugee Board of Canada, 2008). It is salient that a very recent report by the Indonesian National Commission on Human Rights (Komnas HAM) noted: 'Members of the lesbian, gay, bisexual and transgender group continue to face discrimination, marginalization, torture and harassment...with the government denying them their rights as citizens' (Wijaya 2008).

There are pervasive social and cultural norms that exist in Indonesia, promoted by Islamic institutions that demonise and sanction against homosexuality. 'For 
Indonesia's majority Islamic population, these moral precepts in turn are often indistinguishable from community norms. The mechanisms that regulate sexuality are very much a product of the synthesis of customary practices (adat) and Islamic law' (Blackwood 2007: 296). There are no laws that explicitly protect homosexuals from violence and persecution. The onus of moral regulation on matters of sexuality is left squarely to the traditional religious institutions, primarily those that are Islamic.

There does exist, however, an extremely limited cultural and academic space for homosexuals of higher socio-economic class who are able to lead somewhat homosexual-identified lives and ponder the question of 'gay rights.' But this group is composed of only a few people within a nation of 220 million. These are also primarily gay men, not lesbians, as the latter are more or less hidden and their sexuality is regulated by strong, State and religious sponsored discourses on gender (see Blackwood 2007). There have also been attempts by moderate Indonesian Muslims to come to terms theologically with homosexuality, but this is also extremely rare and has not translated into broader discussions of changing legislation or laws to protect homosexuals. Violence against homosexuals has remained invisible in the main and largely unreported due to strong cultural taboos within Indonesian society (Refugee Review Tribunal Australia 2008).

The Indonesian State influences the LG movement, not through banning its organisations, but by seeking to regulate homosexuality by religious, nationalist and even legal means. In terms of law, Indonesia is distinct from Malaysia and Singapore. Blackwood (2007: 294) explains: 'The Indonesian state has maintained a neutral legal stance toward homosexuality.' She adds, 'Despite the absence of laws barring homosexuality among adults, lesbi and gay activist groups in Indonesia point to a pervasive pattern of discrimination directed toward gay, lesbi and waria.'

During the mid 2000s, the Ministry of Justice and Human Rights considered amendments to the Criminal Code. The revised Criminal Code would include specific criminalisation of homosexuality, although it is very difficult to establish the precise status of this Code, as it is still under consideration. Proscriptions against homosexuals have traditionally been regulated through Imams and Islamic law. However, the most significant sign of such laws taken up by regional governments such as Palembang, include a law adopted in 2004 that outlaws prostitution, defined to include 'homosexual 
sex, lesbians, sodomy, sexual harassment, and other pornographic acts' (Ireland: 2006). Recent Islamic law enacted on 14 September 2009 in Aceh (northern Indonesia) criminalised homosexuality with punishment of 100 lashes and up to 8 years in prison.

There have also been increasing vigilante attacks throughout the last few years carried out by thugs and Islamist youths. A very recent example of this has been the forced cancellation by Islamic hard line protestors of a meeting of the Asian chapter of the International Lesbian and Gay Association held in the city of Surabaya. What would have been the first attempt at having such a meeting in Indonesia ended because of significant fears for security and the fact that the police offered no protection (Tan, 2010b). The hotel where the conference was to take place was surrounded by Muslim protestors and the police ordered the conference to end as they could not protect the delegates. The absence of State support for the event was mirrored by 'The minister for religious affairs, Suryadharma Ali,' who 'came forward to say conference organizers could face criminal charges of contempt on religious and decency grounds' (Hartoyo 2010). The influence of the State on the LG movement in Indonesia is powerful, but not in ways that are straightforward or easy to recognise. LG activism has been able to organise certain spaces for representation, for example through LG zines (see Boellstorff 2007), but their effect upon the State and their influence on mainstream Indonesian society is still highly marginal. And as Boellstorff has argued, much of the rhetoric of LG equality advocated in organisations such as Gaya Nusantara are very removed from the everyday experience of LG people in Indonesia (2007: 66).

\section{Conclusion}

The central argument of this chapter has been that in Singapore, Malaysia and Indonesia, the extent to which the LG movement has been influenced by the State can be gauged through the way the State regulates and denies homosexuality through an ensemble of state, civil and religious institutions. What is compelling in surveying the State's response to LG movements across Southeast Asia is that the effects of globalisation, transnational capitalism, transnational queer activism, the Internet and networked communication are mediated by strong nationalist discourses, specific forms 
of localised democracy and civil societies that are not necessarily liberalising in their purpose.

As a consequence, following Tom Boellstorff's observation, the effects of nationalist discourses and the State in Southeast Asia affect the subjectivity of LG people and the LG movement in 'powerful and fundamental ways' (Boellstorff 2007: 215). What can be gauged about Singapore, Malaysia and Indonesia, in their respective contexts, is that the State regulates, oppresses or subjugates the LG movement by ensuring that heteronormativity is central 'in constituting notions of the postcolonial and modern citizen' (Boellstorff 2007: 215). The LG movement in Singapore continues to tiptoe through whatever cultural spaces available to it; in Malaysia an LG movement barely exists and is severely circumscribed by the State's active conflation of civil and Islamic society; in Indonesia, the LG movement finds itself held in by paradoxical forces, abandoned by State support. What can be ascertained in a study of these countries is that LG movements across this part of Southeast Asia are in various phases of uneven development, and not always recognisable through a Western, queer lens. Evelyn Blackwood has rightly remarked, 'transformations are still unfolding, their direction uncertain as competing discourses of morality, modernity, individualism and sexual rights struggle for dominance' (2007: 304). In Southeast Asian societies and cultures where challenging dominant norms is difficult, and where overt declarations of sexual rights and sexual identity is antithetical to those norms, the State continues to influence the existence of LG movements in profound and powerful ways.

\section{References}

Adam, B.D., Duyvendak, J.W. and Krouwel, A. 1999. Gay and Lesbian Movements Beyond Borders? in The Global Emergence of Gay and Lesbian Politics edited by B. D. Adam et al. Philadelphia: Temple University Press, 344-371.

Alagappar, P.N. 2009. The Representation of Homosexuality - A Content Analysis in a Malaysian Newspaper. Language in India 9, 24-47. [Online]. Available at http://www.languageinindia.com/oct2009/ponmalarnewspaper.html [accessed 1 October 2010]. 
Allen, P. 2009. Women, Gender Activism and Indonesia's Anti-Pornography Bill. Intersections: Gender and Sexuality in Asia and the Pacific, 19.

Altman, D. 2001. Global Sex. Crows Nest: Allen and Unwin.

Arondekar, A. 2007. The Voyage Out: Transacting Sex Under Globalization. Feminist Studies, 33(2), 337-349.

Berman, A. 2008. The experiences of denying constitutional protection to sodomy laws in the United States, Australia and Malaysia: You've come a long way and you have a long way to go! Oxford University Comparative Law Forum. [Online] Available at: http://www.allacademic.com/meta/p312271_index.html [accessed 1 October 2010].

Blackwood, E. 2007. Regulation of sexuality in Indonesian discourse: Normative gender, criminal law and shifting strategies of control. Culture, Health and Society, 9(3), 293-307.

Blackwood, E. 2008. Transnational Discourses and Circuits of Queer Knowledge in Indonesia. GLQ: A Journal of Lesbian and Gay Studies, 14(4), 481-507.

Blackwood, E. and Wieringa, S.E. 2007. Globalization, Sexuality and Silences: Women's Sexualities and Masculinities in an Asian Context, in Women's Sexualities and Masculinities in a Globalizing Asia, edited by S. E. Wieringa. New York: Palgrave Macmillan, 1-22.

Boellstorff, T. 2005. The Gay Archipelago: Sexuality and Nation in Indonesia. Princeton: Princeton University Press.

Boellstorff, T. 2007. A Coincidence of Desires: Anthropology: Queer Studies, Indonesia. Durham: Duke University Press. 
Chan, P.C.W. 2009. Shared Values of Singapore: sexual minority rights as Singaporean value. The International Journal of Human Rights, 13(2-3), 279-305.

Foucault, M. 1984. History of Sexuality, vol. 1. Trans. R. Hurley. Harmondsworth, Middlesex: Penguin.

Goh, C.T. 2003. From the valley to the highlands. National Day Rally speech. 17 August, Singapore.

Goh, D. 2008. It's the Gay's Fault: News and HIV as Weapons Against Homosexuality in Singapore. Journal of Communication Inquiry, 32(4), 383-399.

Graham, D. 2006. Dede Oetomo: Welcome to the Gay Archipelago. The Jakarta Post. [Online 19 November 2006] http://www.thejakartapost.com/news/2006/11/19/dedeoetomo-welcome-gay-archipelago.html [accessed 29 January 2010].

Hartoyo. 2010. Longing for acceptance, homosexuals in Indonesia find hatred and discrimination. The Jakarta Globe [Online]. Available at: http://www.thejakartaglobe.com/opinion/longing-for-acceptance-homosexuals-inindonesia-find-hatred-anddiscrimination/369876 [accessed 1 August 2010].

Heng, R. 2001. Tiptoe Out of the Closet: The Before and After of the Increasingly Visible Gay Community of Singapore, in Gay and Lesbian Asia: Culture, Identity, Community, edited by G. Sullivan and P. Jackson. New York: Haworth Press, 81-97.

Heng, R. 2004. Gay Citizens and the Singaporean State: Global Forces, Local Agencies, and Activism in an Asian Polity, in Asian Modernity - Globalization Processes and Their Cultural and Political Localization, edited by Heinrich Böll Foundation. Berlin: Henrich-Boll-Stiftung, 69-79.

Ho, J. 2008. Is Global governance bad for East Asian queers? GLQ: Journal of Lesbian and Gay Studies, 14(4), 457-479. 
Houben, V. 2004. Final Discussion - concluding /summarizing points, in Asian Modernity - Globalization Processes and Their Cultural and Political Localization, edited by Heinrich Böll Foundation. Berlin: Henrich-Boll-Stiftung, 80-83.

Immigration and Refugee Board of Canada 2008, IDN102828.E - Indonesia - The situation of homosexuals; state protection and availability of support groups. [Online]. Available at: http://www.irbcisr.gc.ca/en/research/rir/index_e.htm?action=record.viewrec\&gotorec $=4$ 51966. [accessed 12 August 2010].

Ireland, D. 2006. Indonesia: Gays Fight Sharia Laws. [Online]. Available at: http://www.zmag.org/content/showarticle.cfm?ItemID=11217. [accessed 1 August 2009].

Johnson, C. 2006. Analysing the Politics of Same-Sex Issues in Comparative Perspective: The Strange Similarities between John Howard and Mahathir Mohamad. Intersections: Gender, History and Culture in the Asian Context, 14. [Online] Available at: http://intersections.anu.edu.au/issue14/johnson.html [accessed 1 October 2010].

Johnson, M. Jackson, P. and Herdt, G. 2000. Critical Regionalities and the Study of Gender and Sexual Diversity in South East and East Asia. Culture, Health and Sexuality, 2(4): 361-375.

Kadir, S. 2004. Engagement and Autonomy within the Political Status Quo, in Civil Society and Political Change in Asia: Expanding and Contracting Democratic Space, edited by M. Alagappa. Stanford, California: Stanford University Press, 324-356.

Kasim, Z.M. 2006. Sexuality under attack: the Political Discourse on Sexuality in Malaysia. Women in Action, Isis International [Online]. Available at: http://www.isiswomen.org/index.php?option=com_content\&task=view\&id=270\&Itemi $\mathrm{d}=135$ [accessed 1 October 2010]. 
Laurent, E. 2005. Sexuality and Human Rights: An Asian Perspective, in Sexuality and Human Rights, edited by P. Tahmindjis and H. Graupner. New York: Haworth Press, $163-225$.

Leong, L.W.T. 1995. Walking the Tightrope: The Role of Action for Aids in the Provision of Social Services in Singapore. Journal of Gay and Lesbian Social Services, 3(3): 11-30.

Leong, L. 1997. Singapore, in Sociolegal Control of Homosexuality, edited by D. J. West and R. Green. New York: Plennum, 127-143.

Manderson, L. and Jolly, M. 1997. Introduction: Sites of Desire/Economies of Pleasure in Asia and the Pacific, in Sites of Desire/Economies of Pleasure in Asia and the Pacific, edited by L. Manderson and M. Jolly. Chicago: University of Chicago Press, 126.

Ng, K.K. 1999. The Rainbow Connection: The Internet and the Singapore Gay Community. Singapore: KangCuBine Publishing.

Obendorf, S. 2006. Sodomy as Metaphor, in Postcolonizing the International: Working to Change the Way We Are, edited by P. Darby. Honolulu: University of Hawai'i Press, 177-206.

Obendorf, S. 2010. Email 18 October. Personal Communication.

Oetomo, D. 2010. Self-Portrait: Struggling for Equality and Fairness for LGBTIQ People in Indonesia, in Urgency Required: Gay and Lesbian right are human rights, edited by I. Dubel and A. Hielkema. The Hague: HIVOS, 165-169.

Offord, B. 1999. The Burden of (Homo)sexual Identity in Singapore. Social Semiotics, 9(1), 301-316. 
Offord, B. 2003a. Homosexual Rights as Human Rights: Activism in Indonesia, Singapore and Australia. Oxford: Peterlang.

Offord, B. 2003b. Singaporean queering of the Internet: towards a new form of cultural transmission of rights discourse, in Mobile Cultures: New Media and Queer Asia, edited by F. Martin, C. Berry and A. Yue. Durham, USA: Duke University Press, 133-157.

Offord, B. 2006. Activating Human Rights through Questions of Value and Activism, in Activating Human Rights, edited by E. Porter and B. Offord, B. Oxford: Peterlang, 1126.

Peletz, M.G. 2007. Gender, Sexuality and Body Politics in Modern Asia. Ann Arbor, Michigan: Association for Asian Studies.

Price, D. C. 2003. Singapore: It's in to be out. Time Asia. [Online]. Available at: http://www.time.com/time/asia/magazine/article/0,13673,501030818-474512,00.html. [accessed 20 August 2007].

Ramakrishnan, M. 2000. Homosexuality is a crime worse than murder. Time Asia. Available at www.time.com/time/asia/features/interviews/2000/09/26/int.malay.gay2.html [accessed 1 November 2010].

Refugee Review Tribunal Australia. 2008. IDN33622. RRT Research Response, Indonesia. [Online]. Available at: www.mrtrrt.gov.au/ArticleDocuments/88/IDN33622.pdf.aspx [accessed 1 November 2010].

Sabarini, P 2008. Paradox in heterosexist Indonesia. The Jakarta Post, [Online]. Available at: http://www.thejakartapost.com/node/177241\# [accessed 11 August 2010]. 
Sanders, D. 2005. Flying the Rainbow Flag in Asia. Paper presented at Sexualities, Gender, and Rights in Asia 1st International Conference on Asian Queer Studies, Bangkok. Unpublished paper.

Sanders, D. 2007. Talking about Sex. Fridae.com. [Online]. Available at: fridae.com http://www.fridae.com/newsfeatures/article.php?articleid=2070\&viewarticle $=1$ [accessed 1 July 2010].

Tan, C. 2009. 'But they are like you are me': Gay Civil Servants and Citizenship in a Cosmopolitanizing Singapore. City and Society, 21(1), 133-154.

Tan, S. 2008a. Malaysia's PT Foundation turns 21. Fridae.com [Online]. Available at: http://www.fridae.com/newsfeatures/article.php?articleid=2070\&viewarticle=1. [accessed 1 July 2010].

Tan, S. 2008b. In the spirit of merdeka: Malaysians hold first ever sexuality rights festival. Fridae.com [Online]. Available

at: $\quad$ http://www.fridae.com/newsfeatures/article.php?articleid=2070\&viewarticle=1. [accessed 1 July 2010].

Tan, S. 2010a. 4,000 attend Singapore's second LGBT-supportive public rally. Fridae.com [Online] Available at:

http://www.fridae.com/newsfeatures/2010/05/16/9930.4000-attend singapores-secondlgbt-supportive-public-rally?n=sea\&nm=pink+dot. [accessed 1 July 2010].

Tan, S. 2010b. Islamic protestors force evacuation of ILGA conference participants in Surabaya, 26 March. Fridae.com [Online]. Available at http://www.fridae.com/newsfeatures/2010/03/26/9786.islamic-protestors-forceevacuation-of-ilga-conference-participants-in-surabaya [accessed 1 October 2010].

Tan, K.P. and Jin, G. Lee 2007. Imagining the Gay Community in Singapore. Critical Asian Studies, 39(2), 179-204. 
Weiss, M. 2004. Malaysia: Construction of Counterhegemonic Narratives and Agendas, in Civil Society and Political Change in Asia: Expanding and Contracting Democratic Space, edited by M. Alagappa. Stanford, CA: Stanford University Press. 259-91.

Wijaya, A. 2008. Gays, bisexuals, transgenders still discriminated against: Rights body. The Jakarta Post. [Online 12 November 2008]. Available at: http://www.thejakartapost.com/news/2008/11/12/gays-bisexuals-transgenders-stilldiscriminated-against-rights-body.html [accessed 1 October 2010].

Williams, W. 2009. Homophobia in Islamic Malaysia and Secular China. Nebula, 6(1), $1-20$.

Wilson, A. 2006. Queering Asia. Intersections: Gender, History and Culture in the Asian Region. $14 . \quad$ [Online] Available at: http://intersections.anu.edu.au/issue14/wilson.html [accessed 1 October 2010].

Yue, A. 2007. Creative Queer Singapore: The Illiberal Pragmatics of Cultural Production. Gay and Lesbian Issues and Psychology Review, 3(3), 149-160.

Yusop, N.B.M. 2004. Same Sex Sexuality and Islam in Singapore. Unpublished MA Thesis. Singapore: National University of Singapore. 